\title{
Thermoeconomic Model of Air Conditioning System
}

\author{
Nataliia Zhykharieva, Mykhailo Khmelniuk ${ }^{*}$ \\ Odessa National Academy of Food Technologies, 112 Kanatna St., Odessa, 65039, Ukraine
}

Received: April 08, 2019. Revised: November 14, 2019. Accepted: November 21, 2019.

(C) 2019 The Authors. Published by Lviv Polytechnic National University.

\begin{abstract}
The mathematical model of the air conditioning system has been developed. It is based on the analysis of thermoeconomic energy efficiency indicators and it is solved in a complex way: by defining the optimal parameters taking into account the non-stationary heat of the tides and by determining the optimal device for optimizing the operating modes of the refrigeration system. When designing an air-conditioning system, a thermoeconomic analysis was made for an object being created. An important problem of energy saving was solved during the design with taking into account the changes in electricity tariffs. The thermoeconomic model of the refrigeration unit of the air conditioning system with the definition of exergetic indices and exergic losses has been developed. These indices and losses are components of the thermodynamic efficiency criterion for energy systems that provide a minimum of reduced costs. Analysis of the model allowed obtaining an analytical decision, on the basis of which we can determine the optimal conditions for designing this air conditioning system and its operating modes.
\end{abstract}

Keywords: exergy; analysis; thermoeconomic optimization; air conditioning; refrigeration units; electricity tariffs; heat exchange.

\section{Introduction}

In the conditions of accelerating scientific and technological progress, the design of an energy-efficient air conditioning system becomes important as its solution, in addition to increasing capital investment efficiency, ensures its energy saving, material saving and improves the working conditions of people and the environment. The design, construction and operation of air conditioning systems require large financial and energy costs. The volume of investments is so great that reducing it even by a few percent by setting optimal system and installation parameters provides significant cost savings.

\section{Optimization of air conditioning system}

The mathematical model of the air conditioning system is based on the analysis of thermoeconomic energy efficiency indicators that can be solved in a complex way: the definition of optimal parameters; determination of the optimal device and optimization of operating modes of the refrigerating system.

The model takes into account that the energy of the refrigeration unit can be transmitted in the form of thermal and mechanical work in optimal conditions of the compressor. On the basis of the conducted analysis, the thermoeconomic optimization of the central air-conditioning system and the typical single-stage cooling system was performed. Studying such complex systems as air conditioning systems in the air requires system analysis using mathematical modeling methods. For this purpose, the air conditioning system is subdivided into subsystems and separate elements, for which then a quantitative analysis is performed on the basis of mathematical models of subsystems.

\footnotetext{
"Corresponding author. Email address: hmel_m@ukr.net
}

This paper should be cited as: N. Zhykharieva, M. Khmelniuk. Thermoeconomic model of air conditioning system. Energy Engineering and Control Systems, 2019, Vol. 5, No. 2, pp. 66 - 74. https://doi.org/10.23939/jeecs2019.02.066 
The aim of the work is to optimize the air conditioning system by minimizing the costs incurred.

For the principal scheme of the microclimate air conditioning system, the input and output parameters of each subsystem and system as a whole are indicated. For each subsystem, the independent control variables are assigned, which, along with the input variables, allows you to determine the output parameters, as well as the subsystem costs listed. At the stage of optimization of design decisions stochastic changes in external climatic influences on the house and heat and gas modes in the premises are not taken into account. Estimated input parameters are determined at the most unprofitable combinations of the characteristics of the external climate of heat and gas loads and the given coefficient in the room. The probabilistic statistical nature of the change of these parameters is taken into account when optimally designing an air conditioning system.

Optimization of air conditioning system is carried out in three stages. The main equations of the model are the equation of balance of air, total heat, moisture, gases and apparent heat indoors: (1) - (4).

At the first stage, the structure and performance of the air conditioning system, the nature and the load are optimized.

At the second stage, optimization of subsystems is carried out according to various technological and constructive parameters. Finally, in the third stage, the basic variants of the structure and performance of the air conditioning system are optimized along with optimal subsystem variants. In this case, all possible combinations are considered.

$$
\begin{aligned}
& G_{\mathrm{a}} k \int_{\tau_{\mathrm{p}}}^{\tau_{\mathrm{k}}} \frac{\partial h_{\mathrm{vt}}}{\partial \tau}=G_{\mathrm{p} 1} \cdot h_{\mathrm{p} 1}-G_{\mathrm{vt} 1} \cdot h_{\mathrm{vt} 1}-G_{\mathrm{p}} \cdot h_{\mathrm{p}}+\sum_{i=2}^{n} G_{\mathrm{p} i} \cdot h_{\mathrm{p} i}-\sum_{j=2}^{n} G_{\mathrm{vtj}} \cdot h_{\mathrm{v} j}+\Delta Q+\Delta Q^{\prime} . \\
& G_{\mathrm{a}} \int_{\tau_{\mathrm{u}}}^{\tau_{\mathrm{k}}} \frac{\partial d_{\mathrm{vt}}}{\partial \tau}=G_{\mathrm{p} 1} \cdot d_{\mathrm{p}}-G_{\mathrm{vt} 1} \cdot d_{\mathrm{vt} 1}-G_{\mathrm{p}} \cdot d_{\mathrm{p}}+\sum_{i=2}^{n} G_{p i} \cdot d_{\mathrm{p} i}-\sum_{j=2}^{n} G_{\mathrm{vtj}} \cdot d_{\mathrm{vtj}}+\Delta W+\Delta W^{\prime} . \\
& G_{\mathrm{a}} \int_{\tau_{\mathrm{p}}}^{\tau_{\mathrm{k}}} \frac{\partial \chi_{\mathrm{vt}}}{\rho_{\mathrm{v}} \partial \tau}=G_{\mathrm{p} 1} \cdot \frac{\chi_{\mathrm{p} 1}}{\rho_{\mathrm{p} 1}}-G_{\mathrm{vt} 1} \cdot \frac{\chi_{\mathrm{vv} 1}}{\rho_{\mathrm{vt} 1}}-G_{\mathrm{p}} \cdot \frac{\chi_{\mathrm{p} 1}}{\rho_{\mathrm{p} 1}}+\sum_{i=2}^{n} G_{\mathrm{p} i} \cdot \frac{\chi_{\mathrm{p} i}}{\rho_{\mathrm{p} i}}-\sum_{j=2}^{n} G_{\mathrm{vv} j} \cdot \frac{\chi_{\mathrm{v} j}}{\rho_{\mathrm{vv} j}}+\Delta M_{\mathrm{g}} . \\
& G_{\mathrm{a}} \cdot c_{p} \int_{\tau_{\mathrm{n}}}^{\tau_{\mathrm{k}}} \frac{\partial t_{\mathrm{vt}}}{\partial \tau}=c_{p} \cdot\left(G_{\mathrm{p} 1} \cdot t_{\mathrm{p} 1}-G_{\mathrm{v} 11} \cdot t_{\mathrm{v} 1}-G_{\mathrm{p}} \cdot t_{\mathrm{p}}+\sum_{i=2}^{n} G_{\mathrm{p} i} \cdot t_{\mathrm{p} i}-\sum_{j=2}^{n} G_{\mathrm{v} t j} \cdot t_{\mathrm{v} j}\right)+\Delta Q_{\mathrm{y}}+\Delta Q^{\prime},
\end{aligned}
$$

where $G_{\mathrm{a}}, G_{\mathrm{vt}}, G_{\mathrm{p}}$ are inflow, outflow and recirculation flow rates of air, $\mathrm{kg} / \mathrm{s} ; h_{\mathrm{n}}, h_{\mathrm{vt}}, h_{\mathrm{p}}$ are specific enthalpies of inflow, outflow and recirculation air flows, $\mathrm{kJ} / \mathrm{kg} ; d_{\mathrm{n}}, d_{\mathrm{vt}}, d_{\mathrm{p}}$ are moisture contents of inflow, outflow and recirculation air flows, $\mathrm{g} / \mathrm{kg} ; t_{\mathrm{a}}, t_{\mathrm{vt}}, t_{\mathrm{p}}$ are temperatures of inflow, outflow and recirculation air flows, ${ }^{\circ} \mathrm{C} ; \frac{\chi_{\mathrm{n}}}{\rho_{\mathrm{n}}}$, $\frac{\chi_{v t}}{\rho_{\mathrm{vt}}}, \frac{\chi_{\mathrm{p}}}{\rho_{\mathrm{p}}}$ are concentrations and densities of inflow, outflow and recirculation air flows; $\Delta G, \Delta Q, \Delta W, \Delta M_{\mathrm{g}}$, $\Delta Q_{\mathrm{y}}$ are unbalances of air flow rate, total heat, moisture, mass of gas and apparent heat.

The mathematical model of optimization of cooling air conditioning system is based on energy indicators that can be solved in a complex way. Energy in the refrigeration system can be transmitted in the form of thermal and mechanical work.

Taking into account the dynamic processes at the boundaries of the air environments of the multilayer body and the joint solution of the heat balance equations for stable and unstable modes, the differential equations of thermal equilibrium are obtained. Also, when calculating the thermal load, account is taken of non-stationary flow of heat from people, equipment, and lighting. 
The practical solution of the problem of increasing the efficiency of air conditioning systems depends on the mathematical modeling of the climatic mode of the facility, which allows to obtain the value of the target function for the variants of equipment kits together with the variants of thermal resistance of the fences during the normative lifetime for a short period of time and at small costs. As a result, the payback period of the options for energy saving equipment and the amount of savings received after reaching the payback time before the expiry of the normative term must be obtained [1], [2].

It should be noted that energy conservation is most effective if it is carried out at all stages of the life cycle of the facility from the choice at the stage of designing the climatic equipment and the value of the thermal resistance of the fences, the feasibility of using renewable energy sources, the objective and highly qualified energy audit by the results of the first year of operation and energy management until the moment of capital modernization of the facility or its complete stop before the utilization of the equipment.

So, based on the results of the first year of operation, it is desirable to compare the electricity consumption by the meter readings with the calculations results, which determined the choice of energy saving equipment and the ratio of the cost of passive (fence) and active (equipment) facilities for ensuring the microclimate of the facility.

Based on the results of additional mathematical modeling, taking into account the actual energy consumption for the first year of operation, recommendations may be adopted, for example, for the installation of additional energysaving equipment, reinforcement of the insulation of the fences, reduction of the period between filter cleaning.

Taking into account the above, we propose and test the following target function of joint optimization of the thermal protection of the facility (thermal resistance of the enclosures of the premises), which ensures the given microclimate, and the efficiency of the energy-saving climatic equipment of the active system of providing this microclimate. Target function of joint optimization of the total cost of thermal protection of premises and climatic equipment, throughout the year provide a given microclimate.

The developed target function is the difference between the initial additional investment in energy saving equipment and the additional thermal protection and economy over 7 years of operation, obtained from this equipment and increased thermal protection, which provides a minimum of cost.

We suggest determining the target function $\left(P_{t f}\right)$ for joint optimization taking into account the possible change in the value of electricity and the discount rate of the currency.

$$
P_{t f}=\min \left[\Delta P_{s t}+P_{e s o b}-\sum_{i=1}^{T} \frac{\Delta Q_{g}}{(1+d-R)^{i}}\right],
$$

where $\Delta P_{s t}$ is the additional cost of insulation of external fencing in order to increase the thermal protection of premises with a given microclimate (this may be one external wall or all external walls for a detached facility) [5]; $P_{e s o b}$ is the costs of purchase and installation in the system of energy saving equipment (for example: the recuperator or the complete set of energy saving equipment facility); $i$ is the number of the year after putting the energy saving equipment into operation; $\Delta Q_{g}$ is the annual saving of the cost of consumed electricity as a result of the use of energy saving equipment and strengthening of the thermal protection of the facility (calculated on the average monthly temperature of the environment), $\mathrm{kW} ; d$ is the annual discount rate of the national currency; $R$ is the coefficient of annual growth of value; $p_{e l}$ is the cost of $\mathrm{kW} \cdot \mathrm{h}$ of electricity including VAT.

The target function (5), which is defined for the given options with the help of a program executed in the computing environment MathCAD, allows you to perform a joint optimal choice of the thermal protection option of the object and the set of energy-saving.

Target function (5) is universal in nature and can be performed to determine the payback period.

The period of settlement operation $\mathrm{T}=7$ years is proposed for further discussion. It is assumed that the payback period of energy saving equipment is equal to the guarantee period for this equipment 2-4 years, and the term for making a profit after the payback period is equal to the initial investment in energy saving measures, taking into account the discount rate within 3-5 years. 


\section{Mathematical aspects of thermoeconomic analysis of air conditioning systems}

Using one of the directions of the exergic analysis, thermoeconomic diagnostics [1], [3], [4], an assessment of the energy-economic efficiency of the air-conditioning system was performed.

To optimize such complex systems as refrigeration units, the thermoeconomic method was used, developed by M. Tribus and implemented in the works of V. Onosovsky [5], where exergy is chosen as a generalizing thermodynamic characteristic. The main idea of the method is to construct a thermo-economic model, which allows for the introduction of a closed circuit of a refrigeration unit with feedback links in the form of a chain of individual zones or branched chains, which greatly simplifies the calculations.

This article shows the possibility of using a thermoeconomic method for optimizing the cooling system of a central air conditioning system with solving energy conservation problems.

When constructing a thermoeconomic model, assumptions are made:

- the heat loss due to the external surface of the equipment is not taken into account; the installations under consideration in the heat exchange of the working body with the surrounding are considered;

- pressure loss in shut-off valves, in water and ammonia pipelines are taken into account by aggregate indicators in the amount of pressure losses of the respective apparatus;

- no account was taken of the cost of the building of the engine room, the number and salary of the staff, the cost of the initial refueling of the oil system and refrigerant;

- the cost of fittings, elements of automation, pipelines and auxiliary equipment was not taken into account;

- overheating of the suction steam $\left(\Delta T_{p}\right)$ and overcooling of the liquid working body before the control valve $\left(\Delta T_{v}\right)$, which was not optimized, but was taken on the basis of reference data.

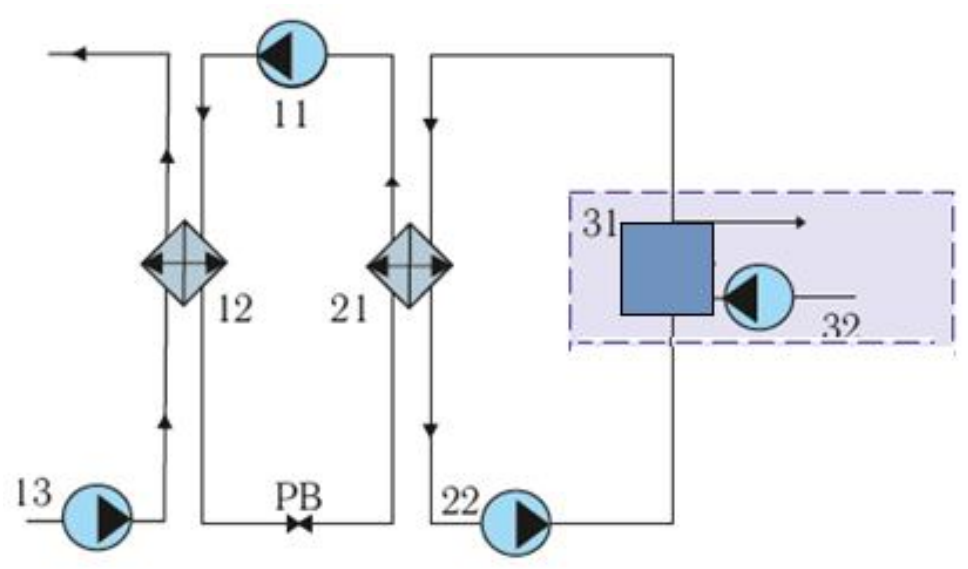

Fig.1. Cooling system for air conditioning systems for the thermoeconomic model.

The scheme of the refrigeration unit (Fig.1), taking into account the assumptions made, can be depicted in the form of a series of three connected zones. Zone 1 includes: compressor 11 with an electric motor, a condenser 12, a cooling water pump with an electric motor and a regulating valve 13. Zone 2 includes: evaporator 21 for cooling the intermediate refrigerant and a pump with an electric motor, which ensures cooling of the refrigerant. Zone 3 includes: central air conditioning system 31 and fan with electric motor.

The reduced costs $(P V)$ were chosen for the target function. These costs can be described by the following expression

$$
P V=\left(P_{e_{i}} \cdot \tau_{i}\right)\left(e_{11}+e_{13}+e_{32}+e_{22}\right)+P_{w} \cdot V_{\mathrm{cv}_{a}}+\left(z_{11}+z_{12}+z_{13}+z_{21}+z_{22}+z_{31}+z_{32}\right) \cdot \tau
$$

where $P_{e_{i}}$ is the cost of electricity at different rates: night, peak and half-baked with the appropriate time, $\mathrm{UAH} /(\mathrm{kW} \cdot \mathrm{h}) ; \tau_{i}$, hours; $V_{c v_{a}}=0.1$ is the volume consumption of fresh water, $\mathrm{m}^{3} / \mathrm{h} ; e_{11}$ is the exergy of the 
compressor motor $11 ; e_{13}$ is the exergy of water pump motor $13 ; e_{32}$ is the exergy of the electric motor of the conditioner; $e_{22}$ is the exergy of the fan motor $22 ; z_{11}+z_{12}+z_{13}+z_{21}+z_{22}+z_{31}+z_{32}$ are normative deductions of individual elements.

In each zone, the specific depreciation deductions and costs for the current repair of the relevant items of equipment are determined:

$$
z_{i}=\frac{\left(k_{\mathrm{a}_{i}}+k_{\mathrm{r}_{i}}\right) \cdot c_{i}}{\tau_{\mathrm{p}_{i}}},
$$

where $k_{\mathrm{a}_{i}}$ is the normative coefficient of depreciation for $i$-th element; $k_{r_{i}}$ is the deduction rate for the current repairing; $c_{i}$ is the the cost of the $\mathrm{i}$-th installment item, $\mathrm{UAH} ; \tau_{\mathrm{p}_{i}}$ is the number of hours of equipment operation per year, hours/year.

For the obtained value of $Q_{\text {cool }}$

$$
P V=P V\left(\Delta T_{w}, \Delta T_{a}\right)
$$

With the restrictions of $\Theta_{\mathrm{c}}=f\left(\Delta T_{w}\right)$ and $\Theta_{0}=f\left(\Delta T_{\mathrm{a}}\right)$, where $\Theta_{\mathrm{c}}, \Theta_{0}$ are the temperatures of the condenser and the air coolers, that are dependent on $\Delta T_{w}$ and $\Delta T_{\text {air }} ; \Delta T_{w}$ is water temperature drop in the condenser 12; $\Delta T_{\mathrm{a}}$ is the difference in the air temperature passing through the air conditioner 31 [3], [4].

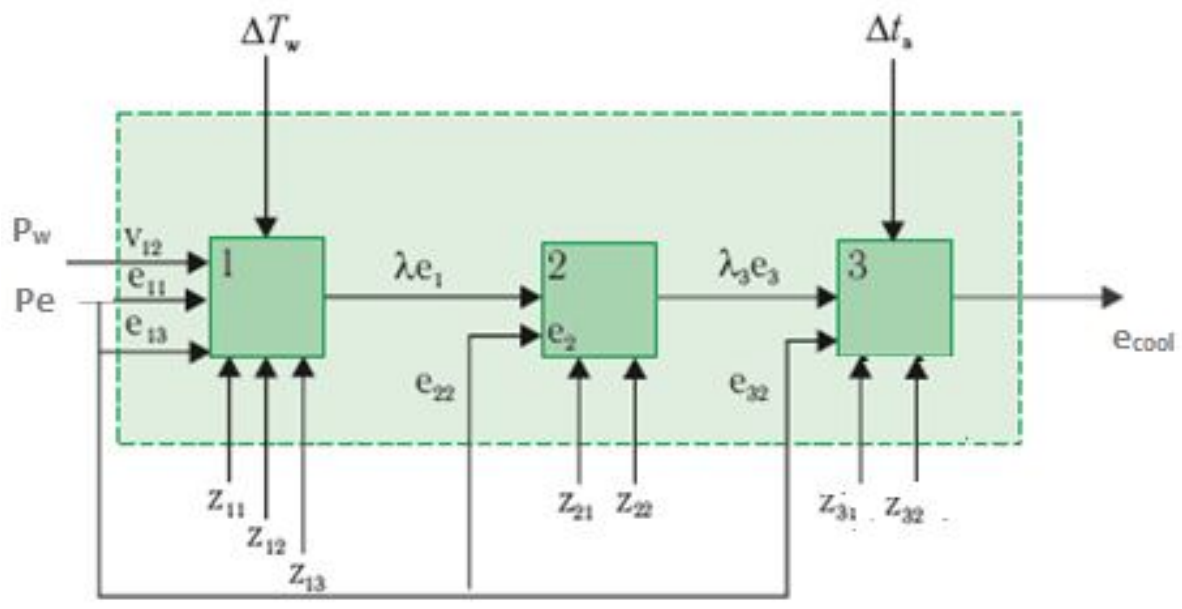

Fig. 2. Thermoeconomic model of a one-stage refrigerating unit of the air conditioning system.

For the considered thermoeconomic model, the specific depreciation deductions and costs for the current repair of the equipment, as well as externally imposed exergy and cooling medium, should be presented in each zone in the form of the function of the exergy stream exiting the given zone and the optimization variables. In this case

$$
\begin{aligned}
& z_{11}=Z_{11}\left(e_{1}, \Theta_{\mathrm{c}}, \Delta T_{w}\right) ; \quad z_{21}=Z_{21}\left(e_{2}, \Theta_{0}, \Delta T_{\mathrm{a}}\right) ; \\
& z_{12}=Z_{12}\left(e_{1}, \Theta_{\mathrm{c}}, \Delta T_{w}\right) ; \quad z_{22}=Z_{22}\left(e_{3}, \Delta T_{w}\right) ; \\
& z_{13}=Z_{13}\left(e_{1}, \Theta_{\mathrm{c}}, \Delta T_{w}\right) ; \quad e_{22}=E_{22}\left(e_{3}, \Theta_{0}, \Delta T_{\mathrm{a}}\right) ; \\
& z_{31}=Z_{31}\left(e_{\mathrm{cool}}, \Theta_{0}, \Delta T_{\mathrm{a}}\right) ; \quad z_{32}=Z_{32}\left(e_{\mathrm{cool}}, \Delta T_{\mathrm{a}}\right) ; \\
& e_{11}=E_{11}\left(e_{1}, \Theta_{\mathrm{c}}, \Delta T_{w}\right) ; \quad e_{13}=E_{13}\left(e_{1}, \Theta_{\mathrm{c}}, \Delta T_{w}\right) ; \\
& e_{32}=E_{32}\left(e_{\mathrm{cool}}, \Delta T_{\mathrm{a}}\right) ; \quad v_{12}=V_{12}\left(e_{2}, \Theta_{\mathrm{c}}, \Delta T_{w}\right) .
\end{aligned}
$$


The magnitudes of exergy flows bind the zone:

$$
\begin{aligned}
& e_{1}=E_{1}\left(e_{\text {cool }}, \Theta_{\mathrm{c}}, \Delta T_{w}\right) ; \\
& e_{3}=E_{3}\left(e_{\text {cool }}, \Theta_{0}, \Delta T_{\mathrm{a}}\right) ; \\
& e_{\mathrm{oxl}}=E_{0}\left(Q_{\text {cool }}, T_{\mathrm{a}}, \Delta T_{\mathrm{nc}}\right) .
\end{aligned}
$$

Solution of the system of equations (9) taking into account the expressions (10) allowed us to determine the values of the variables $\Theta_{\mathfrak{c}}, \Theta_{0}, \Delta T_{w}, \Delta T_{a}$ corresponding to the optimal mode of operation of the refrigeration unit, which provides a minimum of reduced costs. From certain values of temperature pressures and temperature difference of cooling and cooling media, it is possible to calculate the values of the surfaces of heat exchangers and the described volume of the compressor, which provide the optimal mode of operation of the refrigeration unit.

To solve the problem, a mathematical model of this installation was developed, based on the requirements of thermoeconomicity and adequate to the actual technological scheme of the refrigeration plant, taking into account the three-zone tariff for the air conditioning system, taking into account non-stationary heat exchange in the room. Values $z_{i j}$, are proportional to the cost $c_{i j}$ corresponding element of the equipment. In turn, the cost $c_{i j}$ depends on the estimated load on this device. In the first approximation, these dependencies can be considered to be linear.

The cost of each element of the equipment is presented in the form of polynomial equations:

$$
c_{i j}=A_{i j}+B_{i j} \cdot X_{i j} .
$$

Values $X_{i j}$ represent a general characteristic, through which the appropriate equipment was selected; $A_{i j}$, $B_{i j}$ are empirical coefficients.

Determination of the intermediate values of exergy between zones is possible by the formulas:

$$
\begin{aligned}
& \lambda_{1 i}=\left[\left(e_{11}+e_{13}\right) \cdot P_{e_{i}}+P_{w} \cdot V_{\mathrm{cB}_{a}}+\mathrm{z}_{11}+\mathrm{z}_{12}+\mathrm{z}_{13}\right] / e_{1} ; \\
& \lambda_{3 i}=\left[\lambda_{1_{i}} \cdot e_{1}+e_{22} \cdot P_{e_{i}}+\mathrm{z}_{21}+\mathrm{z}_{22}\right] / e_{3} ; \\
& \lambda_{0 i}=\left[\lambda_{3_{i}} \cdot e_{3}+e_{32} \cdot P_{e_{i}}+\mathrm{z}_{31}+\mathrm{z}_{32}\right] / e_{\mathrm{cool}} .
\end{aligned}
$$

In our work, when solving the optimization problems, a numerical method was used that does not require differentiation of the target function, in contrast to the solutions that use the classical methods of differential and variational calculus.

The system of equations (12) correlates between energy dissipation and energy costs in each zone of the thermoeconomic model at certain values of economic indicators $P_{e i}, P_{w}$.

The solution of system (9) allows us to determine the necessary conditions for finding the minimum (6). To solve systems of equations, which are written in the general form, it is necessary to represent them in the form of deployed analytical relations, which are components of the mathematical description of processes occurring in separate elements of the model.

Using the proposed method, the corresponding components of the target function of the $P V$ were determined [4].

The analysis showed that the significant impact on the value of the optimal values $\Theta_{c}, \Theta_{0}, \Delta T_{w}, \Delta T_{\text {air }}$ gives the cost of electricity. In view of this, we have carried out an assessment of the influence of electricity tariffs on the optimal parameters $\Theta_{\mathrm{c}}, \Theta_{0}, \Delta T_{w}, \Delta T_{\text {air }}$.

The purpose of mathematical modeling is the hourly determination of the cold productivity necessary to ensure a comfortable temperature in the room, which operates in a non-stationary mode of heat supply and heat dissipation [7].

In this paper, the method of searching a strained multifunction (Nelder-Mead method) was used. The NelderMead method is one of the most reliable and effective methods of direct search. To determine thermodynamic parameters (specific volume, condensation and boiling pressure, enthalpy at the points of the thermodynamic cycle, enthalpy difference in the process of compression, heat and condensation, etc.), empirical equations were used [8].

Optimization of the operation mode of the refrigeration unit is the final stage of the complex optimization of the cooling system of the fruit and vegetable stores. 
According to the data included in this stage of optimization, mathematical dependences are derived for the calculation of all components of the target function, taking into account exergic losses, as a criterion for thermodynamic efficiency. Intermediate values of exergy are determined between zones.

Cooling air in the air conditioner $\left(\Delta T_{\mathrm{a}}\right)$ is an independent variable and the air temperature entering the air cooler is equal to the air temperature in the chamber $\left(T_{\mathrm{a} 1}=T_{\mathrm{k}}\right)$. Cooling air in the air conditioner $\left(\Delta T_{\mathrm{a}}\right)$ is an independent variable, and the air temperature entering the air cooler is equal to the air temperature in the chamber $\left(T_{\mathrm{a} 1}=T_{\mathrm{k}}\right)$.

Loss of exergy in the irreversible process of transition of heat and $\left(Q_{0}\right)$ from the temperature of the cooled object $(\mathrm{Tv})$ to the average air temperature in the air conditioner $\left(\mathrm{T}_{\mathrm{ai}}\right)$ will make

$$
\Delta e_{\text {cool }}=Q_{\text {cool }} \cdot\left(\frac{T_{\text {n.c }}}{T_{\mathrm{c} . \mathrm{r}}}-\frac{T_{\text {n.c }}}{T_{\text {povv }}}\right) .
$$

The expression for the unit cold-productivity of the installation has the form:

$$
e_{\text {cool }}=Q_{\text {cool }} \cdot\left(\frac{T_{\text {n.c }}}{T_{\mathrm{a}}}-1\right)
$$

The amount of exergy supplied to the electric fan of the air conditioner from the external source is determined by the formula:

$$
e_{\mathrm{vn}}=\frac{V_{\mathrm{pov}} \cdot H_{\mathrm{vn}}}{10^{3} \cdot \eta_{\mathrm{vn}} \cdot \eta_{\mathrm{el} . \mathrm{vn}}} .
$$

where $\mathrm{H}_{\mathrm{vn}}$ is the flow pressure in a float cooler, $\mathrm{Pa}$; flow of air through the air conditioner

$$
V_{p o v}=\frac{Q_{\text {cool }}}{\rho_{c n} \cdot C_{c n} \cdot \Delta T p v} .
$$

An expression for determining the exergy supplied to an air cooler fan from an external source has the form:

$$
e_{32}=\frac{Q_{\mathrm{cool}} \cdot H_{\mathrm{vn}}}{10^{3} \cdot \rho_{\mathrm{cn}} \cdot c_{\mathrm{cn}} \cdot \Delta T_{\mathrm{pv}} \cdot \eta_{\mathrm{vn}} \cdot \eta_{\mathrm{elv}}} .
$$

The loss of exergy at each stage in the capacitor is determined by dependencies:

- overheating zone:

$$
\Delta e_{\mathrm{per}}=G \cdot\left(i_{2}-i_{3}\right) \cdot(-1) \cdot\left(1-\frac{T_{\mathrm{n} . \mathrm{c}}}{T_{\mathrm{c} . \mathrm{p} 2}}\right)
$$

- condensation zone

$$
\Delta e_{\mathrm{kd}}=G \cdot r_{\mathrm{k}} \cdot\left(1-\frac{T_{\mathrm{n.c}}}{T_{\mathrm{k}}}\right)
$$

- cooling zone of liquid coolant

$$
\Delta e_{\text {percoll }}=G \cdot\left(i_{4}-i_{5}\right) \cdot\left(1-\frac{T_{\text {n.c }}}{T_{\text {c.rid } 2}}\right) .
$$

Expression for loss of exergy during throttling through a regulating valve:

$$
\Delta e_{\mathrm{dr}}=G \cdot T_{\mathrm{n} . \mathrm{c}} \cdot c_{\mathrm{c} . \mathrm{rd} 1} \cdot\left(\frac{T_{3}}{T_{0}}-1-\ln \frac{T_{3}}{T_{0}}\right) .
$$


Expression for loss of exergy during throttling through a regulating valve:

$$
\Delta e_{\mathrm{m} . \mathrm{k}}=P_{\mathrm{tr}} \cdot V_{h},
$$

where $P_{\mathrm{tr}}$ is the specific pressure of frictional forces (depending on the type of working body), Pa; $V_{h}$ is the volume described by the compressor pistons, $\mathrm{m}^{3}$.

The amount of exergy $e_{11}$, which must be supplied to the compressor motor (i.e. the power consumed by it) will be determined by summing the exergy flow $e_{1}$, coming out of zone 1 and loss of exergy in that zone.

Summing up the exergy $e_{3}$, coming out of zone 1, and the loss of exergy in this zone, find the exergy that you want to bring to the compressor motor (power consumption):

$$
e_{11}=\frac{e_{1}+\Delta e_{\mathrm{per}}+\Delta e_{\mathrm{kd}}+\Delta e_{\mathrm{prcool}}+\Delta e_{\mathrm{dr}}+\Delta e_{\mathrm{m} . K}}{\eta_{\mathrm{e}_{\mathrm{km}}}} .
$$

The power consumed by the motor of the pump 13 was determined by the formula:

$$
e_{13}=\frac{Q_{\mathrm{k}} \cdot H_{w}}{\left(c_{w} \cdot \rho_{w} \cdot \Delta T_{w} \cdot \eta_{w}-b_{1} \cdot H_{w}\right) \cdot \eta_{\mathrm{dv} . \mathrm{n}}},
$$

where $b_{1}$ is a factor that takes into account what fraction of mechanical energy is converted into heat on the path from the pump to the condenser; $H_{w}$ is the pressure generated by the cooling medium (water) pump; $\eta_{w}$ is the efficiency of the pump of cooling water; $\eta_{\mathrm{dv} . \mathrm{n}}$ is the electric motor efficiency of this pump.

The amount of exergy that the refrigerant stream must have at the inlet of the air conditioner, that is, the amount of exergy included in the third zone of the thermoeconomic model will be:

$$
e_{3}=Q_{\text {zk }} \cdot\left(\frac{T_{\text {n.c }}}{T_{0}}-1\right) \text {. }
$$

We have taken into account that, in contrast to quantities such as water or electricity consumption, which change continuously, the cost of the equipment and, accordingly, the magnitudes of the normative changes discreetly.

The complete cycle of minimization of the resulted expenses is carried out in two stages. First, we minimize the value of $P V$ by considering all variables, including $z_{i j}$, continuous (let's call this stage the first stage of minimization). Then, having determined the optimal values of all the parameters, we choose the closest to the optimal values $z_{i j}$ from a discrete set of values of these quantities. Having fixed the selected values $z_{i j}$, we minimize again (now accepting $z_{i j}$ constant). Let's call this stage the second cycle of minimization. The second minimization cycle determines the optimal mode of operation of a particular installation equipped with the selected devices. If the operation of the already completed refrigeration unit is optimized, the need for the first cycle of minimization is eliminated [9].

In the work on solving optimization problems a numerical method was used that does not require differentiation of the target function, in contrast to the solutions that use the classical methods of differential and variational calculus.

\section{Conclusion}

The results of mathematical modeling allow us to determine the required cold-productivity or heat output and the corresponding power consumption of the system by the average monthly temperatures, and will add a set of correct source data to calculate the full cost of ensuring the microclimate of the facility, including the design, purchase of equipment, operation of the refrigeration unit, installation and maintenance during the period system services, and thus will allow estimating the payback period of the system.

Optimization of the operating mode of the equipment of the refrigeration system of the central air-conditioning system allows reducing the variable part of the cost by about $10-13 \%$, which during the long-term operation of the equipment represents a significant cost savings. 
The developed model of optimal design can be used to create instructions for designing a cooling system for central air conditioning systems.

The obtained dependence of the decision of the thermo-economic model of optimization of a one-stage installation can be applied for the increase of efficiency in air conditioning systems by minimizing the amount of reduced costs.

\title{
References
}

[1] Grachev Yu.G. Fundamentals of optimization of air conditioning systems of the microclimate. - Perm, ed. Perm Polytechnic Institute, 1987. $-80 \mathrm{p}$.

[2] Lozano M., Tozer R. (2014) Thermoeconomics Applied to Air-Conditioning Systems, ASHRAE Transaction, pp. 638-64.

[3] Maneesh D. and S.P.S. Rajput. Thermoeconomic optimization: deviation in procedures followed as a primitive approach to ranking powered vapour compression refrigeration system using R-245C // Journal of Environmental Research And Development, Vol. 3 - No. October- December 2008. - P. 548-568

[4] Tarasova V. A., Kharlampidy D. K. Comparative analysis of thermoeconomic models of formation of exergy cost of cold // Technical gases. - 2013. - No. 6 - P. 55-63

[5] Onosovsky V.V, Krainev V.V 1978, Choice of the optimum operating mode of refrigerating machines and installations using the thermoeconomic analysis method. // Refrigerating machinery. - No. 5, pp. 13-20.

[6] Zhykharieva N.V. Khmelniuk M.G. (2016) Mathematical modeling of building unsteady heat transfer. Refrigeration Engineering and Technology, 52 (6), pp. 75-79. DOI: http://dx.doi.org/10.15673/ret.v52i6.479

[7] Zhykharieva N. (2017) Optimization of conditioning system for premises with non stationary heat exchanger. Norwegian Journal of development of the International Science, 2(5), p. 94-99.

[8] Zhykharieva N. (2014). Mathematical aspects of the thermoeconomic analysis of the refrigeration plant of the vegetable storehouse // Refrigerating machinery and technology - No. 2 (148) - P. 11-15

[9] Zhykharieva N., Khmelniuk M. (2017) Buildings Thermal Protection and Air Conditioning Equipment Over-all Cost Optimization. Refrigeration Engineering and Technology, 53(4), pp. 17-20 (in Ukrainian) DOI: http://dx.doi.org/10.15673/ret.v53i4.706

\section{Термоекономічна модель системи кондиціювання повітря}

\author{
Наталія Жихарєва, Михайло Хмельнюк \\ Одеська наиіональна академія харчових технологій, вул. Канатна 112, м. Одеса, 65039, Україна
}

\section{Анотація}

Розроблена математична модель системи кондиціювання повітря, яка базується на аналізі термоекономічних показників енергоефективності та вирішена в комплексі: визначення оптимальних параметрів; 3 врахуванням нестаціонарних тепло припливів та визначення оптимального пристрою 3 оптимізації режимів роботи холодильної системи. При проектуванні системи кондиціювання повітря проведений термоекономний аналіз створюваного об'єкта, вирішуючи актуальну задачу енергозбереження $з$ урахуванням зміни тарифів на електроенергію. Розроблена термоекономічна модель холодильної установки системи кондиціювання повітря з визначенням ексергетичних показників і ексергетичних втрат, як складових критерію термодинамічної ефективності енергетичних систем, що забезпечують мінімум приведених витрат. Аналіз моделі дозволив отримати аналітичне рішення, на підставі якого визначаються оптимальні умови проектування даної системи кондиціювання і режими їі експлуатації.

Ключові слова: ексергія; аналіз; термоекономічна оптимізація; кондиціювання повітря; холодильні установки; тарифи на електроенергію; теплообмін. 